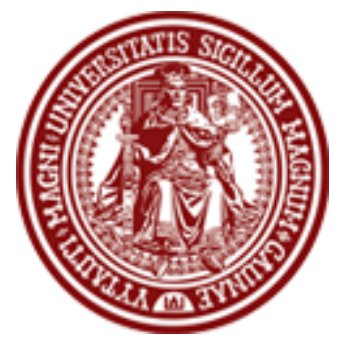

BALTIC JOURNAL OF LAW \& POLITICS

VOLUME 7, NUMBER 1 (2014)

ISSN 2029-0454

http://www.degruyter.com/view/j/bjlp

Cit.: Baltic Journal of Law \& Politics 7:1 (2014): 97-112

DOI: $10.2478 / \mathrm{bjlp}-2014-0006$

\title{
PLEA BARGAINING AS AN EXAMPLE OF THE RECENT CHANGES IN THE FINNISH CIRIMINAL PROCEDURAL PARADIGM
}

\author{
Laura Ervo \\ Professor; Dr. \\ Örebro University, School of Law, Psychology and Social Work (Sweden) \\ Contact information \\ Address: Örebro University, JPS, Fakultetsgatan 1, 70182 Örebro, Sweden \\ Phone: +4619302135 \\ E-mail address: laura.ervo@oru.se
}

Received: May 10, 2014; reviews: 2; accepted: June 30, 2014.

\begin{abstract}
In Finland, a government bill on plea bargaining is now at the parliament. In Estonia, Norway, Denmark, Germany and Latvia they have adopted similar systems already. In Sweden and Iceland plea bargaining is not possible. As a procedural instrument, plea bargaining is something quite new in Europe, and in the Baltic and in the Nordic countries. How does it fit into our systems and into our way of thinking? If we look at the current trends in criminal proceedings fairness, procedural justice, conflict resolution, negotiated law, pragmatically acceptable compromise, procedural truth, party autonomy, court service, communication and interaction are good examples of the topics which are currently being discussed. All these examples indicate that the criminal jurisdiction has become more communal. It has even been said that criminal proceedings have recently become closer civil proceedings, which seems to be quite true. Still, efficiency plays a major role in European adjudication thanks to economic crisis and lack of resources. How to understand the role of plea bargaining in this set? At least the legislator has pointed out the efficiency, the appropriate allocation of resources and the simplifying the criminal proceedings when suggesting adopting the plea bargaining in Finland. The novelty has not been put into philosophical context or into the systemic context of criminal proceedings. It looks like the legislator adopts some single instruments from the foreign legal orders if they seem to fit
\end{abstract}


well into legislators' puzzle to intensify the proceedings and to save the state money. However, there seem to be more coherent trends behind all of that as well - namely, the change of paradigm.

\section{KEYWORDS}

Conflict resolution, criminal proceedings, plea bargaining, material truth, party autonomy, procedural truth, sanction mechanism 


\section{INTRODUCTION}

In Finland, a government bill on the plea bargaining is now at the parliament. ${ }^{1}$ In Estonia, Norway, Denmark, Germany and Latvia they have adopted similar systems already earlier. In Sweden and Iceland plea bargaining is not possible. As a procedural instrument, plea bargaining is something quite new in Europe, and in the Baltic and in the Nordic countries. How does it fit into our systems and into our way of thinking?

If we look at the current trends in criminal proceedings, the situation seems to be controversial depending on the point of view. On the one hand, fairness, procedural justice, conflict resolution, negotiated law, pragmatically acceptable compromise, procedural truth, court service, communication, interaction and plea bargaining are good examples of the topics currently being discussed. All of these examples indicate that the criminal jurisdiction has become more communal, fair and therefore probably softer, from the individual's perspective. It has even been said that criminal proceedings have recently become closer civil proceedings ${ }^{2}$, which seems to be quite true. On the other hand there are at the same time trends which are going in the other direction, that of efficiency-this is the State perspective. Those kinds of examples are for instance the written proceedings in simple and clear criminal cases as well as proceedings in the absence of an accused. The possibility to solve a criminal case in absentia of the accused is quite wide both in Sweden ${ }^{3}$ and in Finland ${ }^{4}$. In Finland it is even possible to have written proceedings in criminal cases ${ }^{5}$. In Sweden, the possibility to use written procedure in criminal cases is not that wide-spread. $^{6}$ The proposal to adopt the plea bargaining system in Finland is again one step towards a more effective criminal procedural system. Is it that the State's aim to intensify the criminal proceedings in order to save money and resources at the same time leads to privatized and softened procedure, which comes even closer to civil proceedings?

\footnotetext{
1 See Todistelu yleisissä tuomioistuimissa, Committee report, Finland, 69/2012; Hallituksen esitys eduskunnalle syyteneuvottelua koskevaksi lainsäädännöksi ja syyttämättä jättämistä koskevien säännösten uudistamiseksi, Government Bill, Finland, 58/2013; Law Committee Report, Finland, 5/2014, on Government Bill 58/2013; and Constitutional Law Committee Report, Finland, 7/2014, on Government Bill 58/2013.

2 Pekka Määttä, Rikosasian joutuisa käsittely: perusoikeus ja tuomarin velvollisuus (Lakimiesliiton kustannus, 2013), p. 647.

${ }^{3}$ The Swedish Code for Juridical Procedure, Chapter 46, Section 15 a.

${ }^{4}$ Chapter 8, Sections 11 and 12 in the Criminal Procedure Act.

${ }^{5}$ Criminal Procedure Act, Chapter 5 a.

${ }^{6}$ The Code for Juridical Procedure, Chapter 45, Section 10 a.
} 


\section{FROM THE SANCTION MECHANISM TOWARDS CONFLICT}

\section{RESOLUTION}

There has been a radical change, especially in the Finnish court culture, since the beginning of the 1990's, based on wide procedural reforms. ${ }^{7}$ Especially, the current, post-modern court culture in civil litigation is based on communication and interaction between the parties and the judge but similar trends can be found even in criminal proceedings. ${ }^{8}$ There has been a big change from the adjudication, ideals of material law and a substantively correct judgment towards the ideal of negotiated law and pragmatically acceptable compromise. In this kind of procedure the judge is seen more as a helper of the parties than an actor who is using his/her public power to make final decisions. The development has gone from the judicial power towards court service. $^{9}$ At the same time there has been a wide-ranging discussion, especially in Sweden, of the ultimate functions of proceedings. Conflict resolution has often been seen as a most important function of (especially) civil proceedings and with this development the perspective has been changed from external towards internal and from retrospective towards prospective point of view. ${ }^{10}$ In this change, the role of parties has been changed from the subservient towards clients, which means that parties are nowadays much more in the center of the proceedings than before.

Proceedings can even be seen as micro politics ${ }^{11}$ and the place for moral discussions. Recently there have been many cases in Finland which have societal meaning even outside the court room and where the discussion and argumentation during the proceedings has general relevance beyond the single case. Some examples include: the cases against the tobacco industry; cases concerning the bank crises in the beginning of 1990 's; and, cases concerning bullying. In these situations, with the help of the media, the public procedure is a new place for moral

\footnotetext{
7 More information in English see Laura Ervo, "The Reform of Civil Procedure in Finland," Civil Justice Quarterly (January 1995); and Laura Ervo, "Scandinavian Trends in Civil Pre-Trial Proceedings," Civil Justice Quarterly (October 2007).

${ }^{8}$ Laura Ervo, "Tie totuuteen": 15; in: Juhlajulkaisu Pekka Viljanen 60 vuotta. Turun yliopisto, 2012.

9 Kaijus Ervasti, Käräjäoikeuksien sovintomenettely. Empiirinen tutkimus sovinnon edistämisestä riitaprosessissa (Oikeuspoliittinen tutkimuslaitos, 2004), p. 433; Vaula Haavisto, "Sovinnot - ikkuna tuomioistuintyön muutokseen. In Sovittelu ja muut vaihtoehtoiset konfliktinratkaisujärjestelmät": 98102; in: Soile Pohjonen, ed., Sovittelu ja muut vaihtoehtoiset konfliktinratkaisujärjestelmät (WSOY, 2001); and Vaula Haavisto, Court Work in Transition. An Activity-Theoretical Study of Changing Work Practices in a Finnish District Court (University of Helsinki, 2002), p. 165 - 251, $260-262$ and 287.

${ }^{10}$ Kaijus Ervasti, "Lainkäytön funktiot," Lakimies (2002): 56 - 62; Tatu Leppänen, Riita-asiain valmistelu todistusaineiston osalta (Suomalainen Lakimiesyhdistys, 1998), p. 32 - 41; Bengt Lindell, Civilprocessen, Andra upplagan (Iustus, 2003), p. 82 - 101; Per Henrik Lindblom, "Processens funktioner - en resa i gränslandet. In Progressiv process. Spridda uppsatser om domstolsprocessen och samhällsutveclingen": 46-58; in: Progressiv process. Spridda uppsatser om domstolprocessen och samhällsutvecklingen (Iustus, 2000); and Jyrki Virolainen, Lainkäyttö. Oikeudenkäynnin perusteet ja lainkäyttöelimet siviili- ja rikosprosessissa (Talentum, 1995), p. 80 - 89.

${ }^{11}$ Sometimes judges make even political resolutions.
} 
discussions. ${ }^{12}$ Criminal proceedings can always be seen as places not only for juridical but also moral discussions, especially in difficult cases where the limits of reprehensible behavior are not clear.

There has also been a change from the normative procedural justice towards a perceived procedural justice, which means that it is not enough that proceedings fulfill the requirements of normative procedural justice but that parties and other actors like witnesses and experts as well as all actors involved in proceedings should in addition subjectively feel that the procedure was fair. The most important function in the adjudication is that the contextual decisions, which the parties are satisfied with, are produced through fair proceedings. In achieving these aims, the communication and interaction of judges and parties are the most important tools. ${ }^{13}$ From this point of view the traditional German concepts of "sein" and "sollen"14 have become closer to one another in terms of procedural fairness. Even if normative fairness and procedural justice from that point of view is based on article 6 of the ECHR and other norms (sollen), the factual situation and the real feelings (sein) of the parties nowadays have more significance in the quality control of fairness. In this shift, the role of parties has changed from being subservient towards clients.

\section{TRENDS IN TRUTH-FINDING}

It has been said that the truth is illusory, incomplete and dependent on the knower and knowledge. The truth is especially very complicated. ${ }^{15}$ Traditionally the aim of procedure has been to find out the material truth. According to the Chapter 17, Section 2 in the Code of Judicial Procedure "after having carefully evaluated all the facts that have been presented, the court shall decide what is to be regarded as the truth in the case." This has been interpreted to refer to the material truth as an aim. However, the real result, the judgment, is always based on the procedural truth, which is what has been proven during the trial. ${ }^{16}$ Still, it has been important to point out the difference between these two dimensions and to aim at the material truth at the illusory level and not to be satisfied with something which is

12 Thomas Wilhelmsson, "(Media)julkinen oikeudenkäynti moraalikeskustelun tilana," Oikeus (2002/3): $252-253$.

${ }_{13}$ Kaijus Ervasti, supra note 9, p. 168; Vaula Haavisto, Court Work in Transition, supra note 9, p. 20; Sakari Laukkanen, Tuomarin rooli (Suomalainen Lakimiesyhdistys, 1995), p. 214; Jukka-Pekka Takala, Moraalitunteet rikosten sovittelussa (Oikeuspoliittinen tutkimuslaitos, 1998), p. 3 - 5; Jyrki Tala, "Luottamus tuomioistuimiin - mitä se on ja tarvitaanko sitä lisää?" Lakimies (2002): 21 - 23; T. R. Tyler, Why people obey the law? (Yale University Press, 1990), p. 94; and Jyrki Virolainen and Petri Martikainen, Pro et contra: tuomion perustelemisen keskeisiä kysymyksiä (Talentum, 2003), p. 5.

${ }^{14}$ I refer here to Hume's Guillotine which means that it is not possible to make claims about what ought to be on the basis of statements about what is.

${ }_{15}$ Carrie Menkel-Meadow, "The Trouble with the Adversary System in a Postmodern, Multicultural World," William and Mary Law Review (1996): 5.

${ }^{16}$ Tauno Tirkkonen, Suomen rikosprosessioikeus I. Toinen, uusittu painos (WSOY, 1969), p. $24-25$. 
false. ${ }^{17}$ The material truth is illusory when the procedural truth is incomplete and dependent on the knower and knowledge.

However, this has been the situation traditionally. In the newer literature the material truth is no longer stressed but it has been pointed out that the result reached in the proceedings is based on the procedural truth only and the material truth as an aim has been underestimated. ${ }^{18}$ Quite recently, the Finnish legislator made a suggestion to change even the above named section. According to the proposal the court shall decide what has been proven in the case. ${ }^{19}$ This decision shall be based on the presented pieces of evidence and other facts that have arisen during the proceedings. In Sweden, this has been the case even before, and both the aim and the result in the proceedings have been based the procedural truth only. According to the Swedish Code for Judicial Procedure, Chapter 35, Section 2, the court shall determine what has been proved in the case after evaluating everything that has occurred in accordance with the dictates of its conscience.

If we compare this development with the traditional dispute resolution we can find some similarities. In olden times, the power to sanction belonged to the village communities. In addition, the family and relatives played the huge role in "criminal procedure" which was based on the aim to find the public peace again and to avoid the spiral of revenge. The significance of the truth became more important only later, when the central power started to develop. At that time also the power to punish moved bit by bit to the state. In Sweden-Finland the private settling of crimes was finally forbidden totally in 1540 and by that royal act the criminal proceedings were moved to the state monopoly. ${ }^{20}$

The increasing complexity of modern life and trials has led to the fact that in conflicts, there are often more than two parties. This development will also affect how the truth as a goal is understood in the proceedings. If we accept that modern conflicts are complex entities which belong to more than only the main parties to the conflict, it may be necessary to accept the relativity of truth and to emphasize

\footnotetext{
17 Laura Ervo, supra note 8: 3.

${ }^{18}$ Dan Frände, Finsk straffprocessrätt (Edita, 2009), p. 366; Johanna Niemi-Kiesiläinen, "Rikosprosessin malleista ja funktioista": 346; in: Risto Haavisto, ed., Juhlakirja Professori Jyrki Virolainen 26.2.2003 (Lapin yliopiston oikeustieteiden tiedekunta, 2003); Mika Huovila, Periaatteet ja perustelut (Suomalainen Lakimiesyhdistys, 2003), p. 179; Santtu Turunen, "Oikeudenkäyntiasiamiehen ja -avustajan vaitiolovelvollisuus oikeudenkäynnissä," Defensor Legis (1999): 496; Jyrki Virolainen and Pasi Pölönen, Rikosprosessin perusteet (WSOY, 2003), p. 174. However, Jokela, Lappalainen and Saranpää have stressed aspects which refer to the material truth and its importance as well (Antti Jokela, Oikeduenkäynti I (Lakimiesliiton Kustannus, 1996), p. 40 - 41; Juha Lappalainen, "Asianosaisen totuusvelvollisuudesta siviiliprosessissa," DL (2001): 993; and Timo Saranpää, Näyttöenemmyysperiaate riita-asiassa (Suomalainen Lakimiesyhdistys, 2010), p. 28 - 29).

${ }^{19}$ Hallituksen esitys eduskunnalle oikeudenkäymiskaaren 17 luvun ja siihen liittyvän todistelua yleisissä tuomioistuimissa koskevan lainsäädännön uudistamiseksi, Government Bill, Finland, 46/2014; and Committee Report 69/2012, supra note 1, p. 215.

$20 \mathrm{Pia}$ Letto-Vanamo, Käräjäyhteisön oikeus. Oikeudenkäyttö Ruotsi-Suomessa ennen valtiollisen riidanratkaisun vakiintumista (Helsingin yliopisto, rikos- ja prosessioikeuden sekä oikeuden yleistieteiden laitos, 1995), p. 85 - 101; and Kevät Nousiainen, Prosessin herruus (Suomalainen Lakimiesyhdistys, 1993), p. $319-320$.
} 
the function of proceedings specifically as conflict resolution. ${ }^{21}$ This can be true even in criminal cases. For instance, if we look at environmental offences, the abovementioned situation seems to be very true. Again we can find some similarities with the ancient conflict resolution. In olden times the crime was the conflict in the whole village society and not only something which belongs to the parties.

The current trend in civil proceedings has for some decades been conflict resolution but it affects even criminal proceedings. There can be seen many aspects which come originally from the conflict resolution model. The material truth and its finding is no longer that important; rather, the most important aim even in the criminal procedure seems more and more often to be that the parties are satisfied and that the conflict between them has been solved fundamentally, finally and by legitimate means. For instance, professor Matti Tolvanen from Finland has said that the material truth is not even the aim in criminal proceedings because the result is anyways based on the procedural truth only. Therefore he thinks that it is more realistic to admit that it is impossible to find out the material truth and the main point in the criminal proceedings is therefore to put the fundamental rights of the victim and the accused into fair balance. ${ }^{22}$ In addition, he says that in the criminal proceedings, the first step is to qualify the current conflict and after that the parties try to prove their views to be correct. After that kind of procedure, the result will be legitimate despite the facts of what really happened in the case. ${ }^{23}$

Courts are no longer that simply organs which use the sovereign's power to punish but more an independent body which protects especially the fundamental rights of citizens. ${ }^{24}$ Even the realization of criminal responsibility can mean that we just solve the conflict which can be solved so that the parties make a friendly settlement, and the material truth in the case will be disregarded. ${ }^{25}$ However, conflict resolution in criminal cases is not identical with conflict resolution in civil cases. In criminal cases, there is always also the public interest present. Still the common factor in both types of procedures is communication, interaction, cooperation and fair trial as the main aim. ${ }^{26}$ The criminal proceedings can be conflict resolution even in the situations where there is no victim in the case. In that case, the perspective is systemic and based on the idea that to be plausible the system must be rested on confidence.

\footnotetext{
${ }^{21}$ Carrie Menkel-Meadow, supra note 15: 5.

22 Matti Tolvanen, "Asianosaisten määräämistoimista rikosprosessissa," Defensor Legis (2003): 1016; and Matti Tolvanen, "Asianosaisten ja tuomioistuimen roolit todistelussa," Lakimies (2006): 1329.

${ }_{23}$ Matti Tolvanen, "Asianosaisten määräämistoimista rikosprosessissa," supra note 22: 1016; and Matti

Tolvanen, "Asianosaisten ja tuomioistuimen roolit todistelussa," supra note 22: 1329.

24 Matti Tolvanen, "Asianosaisten määräämistoimista rikosprosessissa," supra note 22: 1027.

${ }^{25}$ Ibid.: 1016.

${ }^{26}$ Matti Tolvanen, "Asianosaisten ja tuomioistuimen roolit todistelussa," supra note 22: 1343.
} 
If we stress the conflict resolution function, the aim of the material truth is recessive. The most important values in criminal procedure are not the finding out the material truth in a fair way, but the main point especially from the parties' point of view is that they are satisfied with the result and from the system's point of view that it is effective, cost-effective and functional. Thus, the importance of the procedural truth is developing in such a way that the parties may be permitted even to dispose on it.

A similar movement is the restorative justice and mediation in criminal cases, which is one of the current trends as well. Especially Norwegian professor Nils Christie's theory, in which he sees conflicts as our property and resources, ${ }^{27}$ has had a good deal of influence on the Scandinavian, especially Finnish way of thinking. Christie says that that a person's full participation in his or her own conflict presupposes elements of civil law. In contrast, in criminal proceedings the conflict is transformed from a matter between the specific parties at odds to a conflict between one of the parties and the state. Thus especially the victim loses both to the offender and to the state. Based on restorative justice even the accused should meet the conflict itself and the other party, that is the victim, and to participate in the conflict resolution by himself. It is not healthy that it is the state organ which does that for us and serves us too much. Criminal procedure should not be organized like lab tests, where the sample has been sent to the laboratory and the patient is waiting at home for the results made by professionals. The criminal procedure should be based on the actor's personal participation.

The plea bargaining system causes similar effects and we are moving more and more from the material truth towards the procedural truth. In addition, the system may include characteristics of conflict resolution even if it is mainly based on the effectiveness mentality only. ${ }^{28}$

\section{PLEA BARGAINING - CHARACTERISTICS AND COMPARISONS}

The Nordic and Baltic countries Norway, Denmark, Estonia and Latvia have adopted some type of plea bargaining system already, and Finland seems to be the next one to do so. In Sweden, the discussion lead in the opposite direction and the committees which have considered the needs and tools to intensify the criminal proceedings have written already in two reports that there is no need for a plea bargaining system in Sweden, even if the need to intensify the criminal proceedings

\footnotetext{
27 Nils Christie, "Konflikt som eiendom," Tidskrift for rettvitenskap (1977): 113 - 132.

${ }^{28}$ More about this discussion see Laura Ervo, supra note 8: 13 - 15; and Tuula Linna, "Puntarissa plea bargaining - vastassa oikeusturva ja itsekriminointisuoja," Oikeustiede - Jurisprudentia XLIII (2010).
} 
exists there at present. ${ }^{29}$ In Norway, Denmark and Latvia plea bargaining is based on the confession of the accused, which can then lead to resource savings in the form of simpler procedure. In Estonia, the situation is the opposite and the plea bargaining is not based on the confession of the accused, even if the thought that $\mathrm{s} /$ he has committed the crime seems to be presumption in the background and the system is based on the hypothesis of his/her guiltiness. However, no guilty plea is included into the Estonian plea bargaining probably due to procedural reasons. If the plea bargaining procedure will not be successful, then the latter, normal criminal procedure is easier to realize according to the presumption of innocence and ne bis in idem principles if there is no guilty plea in the past. ${ }^{30}$

The role of the victim seems to vary in different countries from an outsider to the situations where the consent of the victim is one of the requirements for the summary proceedings and plea bargaining. ${ }^{31}$

In Finland the proposed system will be based on the confession and the consent of the victim. The aim is to save resources by having easier proceedings in these negotiated cases. Still, Finland is going even further because plea bargaining covers even the police investigation level. Investigation can be focused on the confessed crime only, whereas the other suspected but more unclear crimes are not investigated at all in the plea bargaining context. It means, for instance, bargaining even on an investigation and not only by way of proceedings and then sanction. However, fact bargaining will not be allowed. Still, the suspect may by bargaining "choose" even the crimes which will be investigated and which will later lead on the simplified proceedings and probably milder sanctions. ${ }^{32}$ In the Finnish model, the state will win in the form of resource savings and the accused will win in the form of limited police investigations in the cases in which $\mathrm{s} /$ he has committed even more criminal offences, and in simplified procedures and milder sanctions. The victim will not win that much; however, it has been said that the benefit for her/him is in simplified procedures where s/he can for instance avoid meeting the accused or having the duty to provide evidence. ${ }^{33}$ In addition, the confession which is needed

29 Ett effektivare brottsmålsförfarande - några ytterligare åtgärder, Committee Report, Sweden, SOU 2005:117, p. 61 - 64; and Brottmålsprocessen, Committee Report, Sweden, SOU 2013:17, p. 241 243.

30 There has even been discussion in Estonian legal literature about the role and meaning of the confession in plea bargaining and other type of summary or alternative criminal procedures. See, for instance, Eerik Kergandberg, "Expedience of Arrangement in German and Estonian Criminal Care," Juridica International (1/1997); Meris Sillaots, "Arrangement - Form of Procedure Based on Guilty Plea and Presumption of Guilt?" Juridica International (1/1998); and Meris Sillaots, "Admission and Confession of Guilt in Settlement Proceedings under Estonian Criminal Procedure," Juridica International $(11 / 2004)$.

31 There is a comparative summary on the system in the named countries in the Committee Report $26 / 2012$, supra note 1 , p. 28 - 34 .

${ }^{32}$ Government bill 58/2013, supra note 1 .

${ }^{33}$ Ibid. 
usually gives victims better possibilities for being awarded damages as well and this is one more benefit for the victim, of course.

As mentioned already above, in Estonia, the confession is not part of plea bargaining and the accused will not confess but $s /$ he will just give her/his approval for simpler proceedings based on negotiations. Therefore approval is mainly a procedural tool to choose the form of proceedings and to use the party autonomy in this procedural sense. Still, it is not the confession in its substantive sense-in other words, in the meaning of criminal law. There has been some discussion in the legal doctrine on this distinction, its meaning and limits, but Estonia seems to be the only country of the abovementioned examples where plea bargaining has mostly been understood as a procedural tool even if this distinction seems to be a little bit cosmetic, because the whole system is based on the idea of clear crimes in which the accused is guilty even according to her-/himself. ${ }^{34}$

To include or exclude the guilty plea in the plea bargaining is an interesting topic and it can be compared with, especially, the Swedish discussion of if the parties may agree even against the substantive law in civil cases and if the court should confirm also that type of friendly settlements. The party autonomy can, namely, cover only procedural issues, like the choice between the summary and full proceedings or it can be extended to include even the power to decide the case materially when the instrument is including substantive elements as well, in this case of plea bargaining criminal law elements. Therefore plea bargaining can be seen as a procedural instrument where party autonomy covers procedural issues, or it can be seen as a substantive tool where the parties agree on issues which belong to criminal law. In this distinction, the nature and scope of confession plays the main role. The other important issue is the role of the parties, especially if the consent of the victim is needed, and how much the parties will attend to negotiations and decision making, or is it mostly the prosecutor as a state representative who will fix the issue ex officio.

As already mentioned, there has been some discussion in Sweden on the theme of whether the parties have a right to dispose of even substantive matters and the questions of law. However, this discussion covers civil cases only. Especially Lindell has defended this way of thinking and possibilities in that type of power delegation from the state to the parties. ${ }^{35}$ In Finland, the usual comment on

\footnotetext{
34 See Erik Kergandberg, supra note 30; Meris Sillaots, "Arrangement - Form of Procedure Based on Guilty Plea and Presumption of Guilt?" supra note 30; and Meris Sillaots, "Admission and Confession of Guilt in Settlement Proceedings under Estonian Criminal Procedure," supra note 30. However, the reason for this Estonian solution to stress that no confession is needed and that the plea bargaining procedure is not based on the confession, is probably to avoid the collision between plea bargaining and the presumption of innocence.

${ }^{35}$ Bengt Lindell, Partsautonomins gränser (Iustus, 1988), p. 83 - 118.
} 
this topic is a reference to the jura novit curia principle and a comment that the parties may not dispose of the questions of law. ${ }^{36}$

Lindell has compared the disposition of legal matters with the situations of friendly settlement with arbitration. There are some differences between them and Lindell did not find them identical, but some support can be drawn. ${ }^{37}$ One of Lindell's points is that because the parties may achieve the same result in making procedural disposes - for instance with acknowledge of the claim or confession on the fact or with burden of proving an allegation - why should the disposal of matters of law (substantive law) be forbidden. According to him there are also many judges in practice who will follow the dispositions of the parties even when they cover legal questions. ${ }^{38}$

Lindell has put emphasis on judicial relief. The content of this term is not only the idea to achieve a judgment which has been achieved strictly according to substantive law. It covers also access to a certain procedure where consensus on the substantive legal matters exists. The point then is to stress public peace. ${ }^{39}$ Lindell has also noted that the court may break even in an autonomous way from the request of norm standards. Due to the independence of courts neither officials nor parliament may tell to the court the right interpretation of the norm. ${ }^{40}$ Therefore he seems to think that the idea to confirm the settlement which covers the substantive law is not that radical and as impossible as it looked at first glance, and that it is possible to extend the party autonomy to cover fully even the substantial matters in the legislation.

How do we apply all of this to the criminal law and criminal proceedings? Plea bargaining is an example of this. In the context of plea bargaining the interesting starting point is whether the parties gain the power to decide the substantive, that is, criminal law in the way which binds courts. If this is allowed, the role of courts is seen clearly to be as a client's conflict solver and not as state adjudicators who decide the case in the name of society and follow the law. In civil cases this already is the current situation, but how about criminal cases? Are we ready to take the next step and to allow even that?

Plea bargaining can be put into this new context. However, two questions arise. Is it a tool to allow the substantive dispositions in criminal matters and a tool to delegate state's power back to the people? Or, is it just a procedural instrument to choose a simpler procedure and to save money and other resources?

36 See, for instance, Antti Jokela, Oikeudenkäynnin perusteet. Oikeudenkäynti I (Lakimiesliiton Kustannus, 2005), p. 184.

${ }^{37}$ Bengt Lindell, supra note 35, p. 68.

38 Ibid., p.73.

${ }^{39}$ Ibid., p. 85.

${ }^{40}$ Ibid., p. 104. 
This type of discussion on procedural fundamental values applied to plea bargaining is failing. ${ }^{41}$ Legislators have proposed new instruments without considering their effects on the criminal procedural paradigm. Plea bargaining has been seen as a technical instrument only and its links to understanding criminal law and criminal proceedings have been ignored. Plea bargaining is not a technical instrument only. Adopting and using this instrument certainly changes the surrounding world as well.

In Sweden, plea bargaining as an instrument for savings has been rejected with the short and simple comment that it does not fit into the Swedish system and that there is no need for that type of intensification. At the same time Finnish legislators have proposed to adopt plea bargaining quite widely in order to save resources without any discussion about fundamental criminal and criminal procedural values. It is time to take care of the changes as a whole and to put the recent development into the procedural and criminal frames we have. Are we ready to change them and if yes, should we be aware of that development which will lead to the fundamental reform in criminal procedural system and the basis to which it is grounded? The change can be positive but it should be considered and conscious.

Is it time to delegate a part of society's and therefore the state's deciding power to the individuals, that is, parties, or is there still a need to take criminal cases to court and make adjunctive decisions by the state authorities? In the name of resources, is it reasonable to accept the party decisions in clear and not that serious crimes covering the way of proceedings only or even in substantial matters like guiltiness and sanctions? If the reply is "yes", there is no need to argue for plea bargaining's suitability to our legal order, but we can focus instead on more unclear and serious crimes in the state courts and delegate the deciding power back to the people in the other cases. The direct reason for this development can be the current lack of recourses but the change cannot be made without fundamental and widely accepted changes in the way of thinking.

\section{CONCLUSIONS}

Conflict resolution, restorative justice, party autonomy and procedural truth are the main trends in criminal proceedings and the law can be seen as a negotiable compromise between the victim and the accused and sometimes even between the state authorities (the prosecutor) and the accused (especially in plea bargaining or when choosing the written procedure or the procedure in absentia). It

\footnotetext{
${ }^{41}$ Constitutional Law Committee Report 7/2014, supra note 1.
} 
looks like the new way of thinking; there is a great change in values, and a fundamental change in the criminal procedural paradigm is occurring. ${ }^{42}$

However, the real situation seems to be simpler. Namely, the state economy seems to be the most important ground to realise those aims of restorative justice, party autonomy, procedural truth and conflict resolution. How should we see the role of plea bargaining in this set? Legislators have pointed out the efficiency, the appropriate allocation of resources and the simplifying of the criminal proceedings when suggesting an adoption of plea bargaining in Finland. ${ }^{43}$ At the same time Swedish legislators have rebutted the plea bargaining - again without any proper discussion - just by mentioning that "it does not fit into our system". Why do we avoid the discussion on ultimate values?

The novelty has not been put into the philosophical context or into the systemic context of criminal proceedings. It looks like legislators adopt (or reject) certain single instruments from the foreign legal orders if they seem to fit well into legislators puzzle, in order to speed up the proceedings and to save the state money.

The criminal process seems to be going towards party autonomy and there is a trend towards increasing the role of parties as well as the atonement instead of the state's monopolistic penal authority. In this respect, criminal proceedings have moved away from the material truth and the penal authority towards societal solution to the conflict where parties are in the centre. At the same time, the privatization of jurisdiction and the financial savings in state economy, lead to the same aims. In plea bargaining all of that will be realized. No wonder that it has been adopted or proposed until now in several member states despite of the fact that it is originally a legal transplant. However, when adapting this type of totally new, unknown tools, they should be put into the philosophical context as well and it should be first discussed how they fulfil the aims and purposes we have in our criminal justice system. Efficiency is just one of those values; I hope there is also something else left despite the European economic crisis and the lack of resources. Therefore we should ask if the state economy is the most important grounds when the trends of restorative justice, party autonomy, procedural truth and conflict resolution are adopted, and are they just suitable ideas and theories to realize that most important aim to save money and resources? Or do we morally aim at more privatised criminal procedural system where the power to decide the case has been

\footnotetext{
42 The similar development in civil proceedings is an even clearer phenomenon (see Laura Ervo, "Changing Civil Proceedings - Court Service or State Economy": 51-68; in: Recent Trends in Economy and Efficiency of Civil Procedure (Vilnius University Press, 2013)).

${ }^{43}$ Government Bill 58/2013, supra note 1.
} 
partly delegated from the state and courts to the prosecutor and parties in order to intensify their participation in decision-making?

In sum, the state has no money left and the people will therefore get their deciding power back. ${ }^{44}$ Are we ready for this?

\section{BIBLIOGRAPHY}

1. Brottmålsprocessen. Committee Report, Sweden, SOU 2013:17.

2. Christie, Nils. "Konflikt som eiendom." Tidskrift for rettvitenskap (1977): 113 $-132$.

3. Constitutional Law Committee Report, Finland, 7/2014, on the Government Bill 58/2013.

4. Ervasti, Kaijus. Käräjäoikeuksien sovintomenettely. Empiirinen tutkimus sovinnon edistämisestä riitaprosessissa. Oikeuspoliittinen tutkimuslaitos, 2004.

5. Ervasti, Kaijus. "Lainkäytön funktiot." Lakimies (2002): 47-72.

6. Ervo, Laura. "Changing Civil Proceedings - Court Service or State Economy": 51-71. In: Recent Trends in Economy and Efficiency of Civil Procedure. Vilnius University Press, 2013.

7. Ervo, Laura. "Scandinavian Trends in Civil Pre-Trial Proceedings." Civil Justice Quarterly (October 2007): 466 - 483.

8. Ervo, Laura: "The Reform of Civil Procedure in Finland." Civil Justice Quarterly (January 1995): 56-64.

9. Ervo, Laura. "Tie totuuteen": 1-16. In: Juhlajulkaisu Pekka Viljanen 60 vuotta. Turun yliopisto, 2012.

10. Ett effektivare brottsmålsförfarande - några ytterligare åtgärder. Committee Report, Sweden, SOU 2005:117.

11. Frände, Dan. Finsk straffprocessrätt. Edita, 2009.

12. Haavisto, Vaula. Court Work in Transition. An Activity-Theoretical Study of Changing Work Practices in a Finnish District Court. University of Helsinki, 2002.

13. Haavisto, Vaula. "Sovinnot - ikkuna tuomioistuintyön muutokseen. In Sovittelu ja muut vaihtoehtoiset konfliktinratkaisujärjestelmät": 83-119. In: Soile Pohjonen, ed. Sovittelu ja muut vaihtoehtoiset konfliktinratkaisujärjestelmät. WSOY, 2001.

\footnotetext{
${ }^{44}$ The first step in this development seems to be that the power is delegated to prosecutors who still are state authorities but the direction is the same.
} 
14. Hallituksen esitys eduskunnalle oikeudenkäymiskaaren 17 luvun ja siihen liittyvän todistelua yleisissä tuomioistuimissa koskevan lainsäädännön uudistamiseksi. Government Bill, Finland, 46/2014.

15. Hallituksen esitys eduskunnalle syyteneuvottelua koskevaksi lainsäädännöksi ja syyttämättä jättämistä koskevien säännösten uudistamiseksi. Government Bill, Finland, 58/2013.

16. Huovila, Mika. Periaatteet ja perustelut. Suomalainen Lakimiesyhdistys, 2003.

17. Jokela, Antti. Oikeudenkäynnin perusteet. Oikeudenkäynti I. Lakimiesliiton Kustannus, 2005.

18. Jokela, Antti. Oikeduenkäynti I. Lakimiesliiton Kustannus, 1996.

19. Kergandberg, Eerik. "Expedience of Arrangement in German and Estonian Criminal Care." Juridica International (1/1997): 76 - 89.

20. Lappalainen, Juha. "Asianosaisen totuusvelvollisuudesta siviiliprosessissa." $D L$ (2001): 993 - 1003.

21. Laukkanen, Sakari. Tuomarin rooli. Suomalainen Lakimiesyhdistys, 1995.

22. Law Committee Report, Finland, 5/2014, on Government Bill 58/2013.

23. Leppänen, Tatu. Riita-asiain valmistelu todistusaineiston osalta. Suomalainen Lakimiesyhdistys, 1998.

24. Letto-Vanamo, Pia. Käräjäyhteisön oikeus. Oikeudenkäyttö Ruotsi-Suomessa ennen valtiollisen riidanratkaisun vakiintumista. Helsingin yliopisto, rikos- ja prosessioikeuden sekä oikeuden yleistieteiden laitos, 1995.

25. Lindblom, Per Henrik. "Processens funktioner - en resa i gränslandet. In Progressiv process. Spridda uppsatser om domstolsprocessen och samhällsutveclingen": 41-85. In: Progressiv process. Spridda uppsatser om domstolprocessen och samhällsutvecklingen. Iustus, 2000.

26. Lindell, Bengt. Civilprocessen, Andra upplagan. Iustus, 2003.

27. Lindell, Bengt. Partsautonomins gränser. Iustus, 1988.

28. Linna, Tuula. "Puntarissa plea bargaining - vastassa oikeusturva ja itsekriminointisuoja." Oikeustiede - Jurisprudentia XLIII (2010): 189-262.

29. Määttä, Pekka. Rikosasian joutuisa käsittely: perusoikeus ja tuomarin velvollisuus. Lakimiesliiton kustannus, 2013.

30. Menkel-Meadow, Carrie. "The Trouble with the Adversary System in a Postmodern, Multicultural World." William and Mary Law Review (1996): 5 44.

31. Niemi-Kiesiläinen, Johanna. "Rikosprosessin malleista ja funktioista": 337348. In: Risto Haavisto, ed. Juhlakirja Professori Jyrki Virolainen 26.2.2003. Lapin yliopiston oikeustieteiden tiedekunta, 2003.

32. Nousiainen, Kevät. Prosessin herruus. Suomalainen Lakimiesyhdistys, 1993. 
33. Saranpää, Timo. Näyttöenemmyysperiaate riita-asiassa. Suomalainen Lakimiesyhdistys, 2010.

34. Sillaots, Meris. "Admission and Confession of Guilt in Settlement Proceedings under Estonian Criminal Procedure." Juridica International (11/2004): 116 124.

35. Sillaots, Meris. "Arrangement - Form of Procedure Based on Guilty Plea and Presumption of Guilt?" Juridica International (1/1998): 76 - 149.

36. Syyteneuvottelu ja syyttämättäjättäminen. Committee Report, Finland, OMM 26/2012.

37. Takala, Jukka-Pekka. Moraalitunteet rikosten sovittelussa. Oikeuspoliittinen tutkimuslaitos, 1998.

38. Tala, Jyrki. "Luottamus tuomioistuimiin - mitä se on ja tarvitaanko sitä lisää?" Lakimies (2002): 3 - 33.

39. Tirkkonen, Tauno. Suomen rikosprosessioikeus I. Toinen, uusittu painos. WSOY, 1969.

40. Todistelu yleisissä tuomioistuimissa. Committee Report, Finland, 69/2012.

41. Tolvanen, Matti. "Asianosaisten ja tuomioistuimen roolit todistelussa." Lakimies (2006): 1325 - 1343.

42. Tolvanen, Matti. "Asianosaisten määräämistoimista rikosprosessissa." Defensor Legis (2003): 1009 - 1027.

43. Turunen, Santtu. "Oikeudenkäyntiasiamiehen ja -avustajan vaitiolovelvollisuus oikeudenkäynnissä." Defensor Legis (1999): 468 - 499.

44. Tyler, T. R. Why people obey the law? Yale University Press, 1990.

45. Virolainen, Jyrki, and Pasi Pölönen. Rikosprosessin perusteet. WSOY, 2003.

46. Virolainen, Jyrki, and Petri Martikainen. Pro et contra: tuomion perustelemisen keskeisiä kysymyksiä. Talentum, 2003.

47. Virolainen, Jyrki. Lainkäyttö. Oikeudenkäynnin perusteet ja lainkäyttöelimet siviili- ja rikosprosessissa. Talentum, 1995.

48. Wilhelmsson, Thomas. "(Media)julkinen oikeudenkäynti moraalikeskustelun tilana." Oikeus (2002/3): 252-264. 